Gulawentah: Jurnal Studi Sosial

ISSN 2528-6293 (Print); ISSN 2528-6871 (Online)

Vol. 5, No. 2, Desember 2020, Hal 98-106

Tersedia Online: http://e-journal.unipma.ac.id/index.php/gulawentah

\title{
Penggunaan Aplikasi “AMELIA” Pembelajaran dalam Jaringan Mahasiswa Jurusan Pendidikan Sejarah
}

\author{
Aldegonda Evangeline Pelealu*, Eka Yuliana Rahman, dan Aksilas Dasfordate \\ Jurusan Pendidikan Sejarah, Universitas Negeri Manado, Jl. Raya Tondano, Kabupaten \\ Minahasa, Sulawesi Utara 95618, Indonesia \\ Email:*aldegondapelealu@unima.ac.id; ekayulianarahman@unima.ac.id; \\ aksilasdasfordate@unima.ac.id
}

Naskah diterima: 1/9/2020; Revisi: 15/10/2020; Disetujui: 20/11/2020

\begin{abstract}
Abstrak
Knowledge Management (Manajemen pengetahuan) merupakan proses rangkaian kegiatan penguasaan teknologi informasi yang tidak lepas dari pengelolaan. Learning Management System atau LMS elektronik sebuah platform untuk penyebaran materi pembelajaran online guna meningkatkan kinerja akademik dengan penyediaan sumber daya berbasis web. Kendala yang sering dihadapi di institusi pendidikan dalam menerapkan E-Learning sistem kurang menyesuaikan dengan kondisi dan tingkat knowledge dari penggunanya. Penelitian ini bertujuan untuk mengetahui efektivitas penggunaan aplikasi AMELIA (Aplikasi Manajemen Pembelajaran dalam Jaringan UNIMA) serta kemudahan menggunakan aplikasi pembelajaran daring pada jurusan Pendidikan Sejarah Universitas Negeri Manado. Penelitian ini dilakukan dengan menggunakan metode penelitian survey deskriptif, untuk sampel pada penelitian ini mahasiswa semester 2 angkatan 2019 Jurusan Pendidikan Sejarah Universitas Negeri Manado. Teknik pengumpulan data menggunakan angket. Dalam penelitian ini satu rombongan belajar sebanyak 38 mahasiswa dan sekitar 25 orang atau 65,8\% yang mengisi form efektif, dan kurang efektif sebanyak 13 orang atau 34,2 \% dalam proses pelaksanaan pembelajaran menggunakan aplikasi Amelia dikondisi wabah Covid-19. Kemudahan dalam akses oleh 29 orang atau sekitar $76,3 \%$ mengatakan kesusahan dalam mengakses karena masalah internet maupun kekuranga kuota dan 9 orang atau sekitar 23,7\% mudah dalam mengakses aplikasi Amelia. Kemampuan menggunakan Fitur dalam aplikasi Amelia 22 orang atau sekitar 57,9\% mengungkapkan tidak mudah dan 16 orang atau sekitar 42,1\% mengatakan mudah dalam menggunakan fitur yang terdapat dalam LMS UNIMA yakni Aplikasi Amelia. Penggunaan alat elektronik oleh mahasiswa dalam mengikuti kuliah menggunakan aplikasi Amelia yaitu 37 orang atau sekitar 97,4\% menggunakan Handphone dan 1 orang atau 2,6\% menggunakan Laptop. Persepsi mahasiswa dengan penggunaan aplikasi Amelia untuk pembelajaran dalam jaringan dirasa efektif dimana semua materi mata kuliah yang diprogram telah tersedia dalam satu aplikasi.Kondisi pandemi mempengaruhi tingginya tingkat efektivitas dalam pembelajaran secara daring dimana saat ini menghadapi wabah Covid-19 peraturan menteri masih menghimbau untuk kuliah dalam jaringan dan meminimalisir kegiatan yang berada di kampus.
\end{abstract}

Kata kunci: Knowledge Management, Learning Management System, Aplikasi Amelia, Efektivitas Pembelajaran dalam jaringan

DOI: 10.25273 /gulawentah.v5i2.7393

Some rights reserved. 


\title{
Use of The "AMELIA" Application of Learning in Student Networks Department of Historical Education
}

\begin{abstract}
Knowledge Management is the process of a series of information technology mastery activities that cannot be separated from management. Learning Management System or electronic LMS is a platform for the dissemination of online learning materials to improve academic performance by providing web-based resources. The obstacles that are often faced in educational institutions in implementing the E-Learning system do not adapt to the conditions and knowledge levels of its users. This study aims to determine the effectiveness of using the AMELIA application (Learning Management Application in the UNIMA Network) and the ease of using online learning applications in the Department of History Education, Manado State University. This research was conducted using a descriptive survey research method, for the sample in this study the 2nd semester of 2019 students of the Department of History Education, Manado State University. The data collection technique used a questionnaire. In this study, a study group of 38 students and about 25 people or $65.8 \%$ who filled out effective forms, and less effective as many as 13 people or $34.2 \%$ in the process of implementing learning using the Amelia application under the conditions of the Covid-19 outbreak. Ease of access by 29 people or around $76.3 \%$ said that it was difficult to access because of internet problems or lack of quota and 9 people or about $23.7 \%$ found it easy to access the Amelia application. The ability to use the features in the Amelia application, 22 people or about $57.9 \%$ said it was not easy and 16 people or about $42.1 \%$ said it was easy to use the features contained in LMS UNIMA, namely the Amelia Application. The use of electronic devices by students in attending lectures using the Amelia application, namely 37 people or around $97.4 \%$ using cellphones and 1 person or $2.6 \%$ using laptops. Students' perceptions of using the Amelia application for online learning are considered effective where all programmed course material is available in one application. Pandemic conditions affect the high level of effectiveness in online learning where currently facing the Covid-19 outbreak, the ministerial regulation still calls for lectures in network and minimize activities on campus.
\end{abstract}

Keywords: Knowledge Management, Learning Management System, Amelia Application, Learning Effectiveness in Network.

\section{Pendahuluan}

Knowledge Management (KM) banyak diterapkan di berbagai organisasi, termasuk di institusi pendidikan seperti di Universitas Negeri Manado. Sistem yang mendukung berjalannya proses dalam KM disebut sebagai KM Sistem. Salah satu contoh KM Sistem di lingkungan pendidikan adalah Learning Management System atau dikenal sebagai sistem e-learning. Penerapan e-learning di institusi pendidikan sering mengalami kegagalan karena penggunannya kurang merasa nyaman dengan sistem atau sistem tidak dibangun sesuai dengan kondisi dan tingkat knowledge dari penggunanya (Solichin, 2009). Manajemen pengetahuan melibatkan identifikasi dan analisis yang tersedia dan membutuhkan pengetahuan dan selanjutnya perencanaan dan pengendalian tindakan untuk mengembangkan aset pengetahuan sehingga dapat memenuhi tujuan organisasi (Halawi, McCarthy, \& Aronson, 2007)..

Konsep manajemen pengetahuan ini meliputi pengelolaan sumber daya manusia (SDM) dan teknologi informasi (TI) dalam tujuannya untuk mencapai organisasi institusi yang semakin baik sehingga mampu memaksimalkan kualitas proses pembelajaran. Perkembangan teknologi informasi memang memainkan peranan yang penting dalam konsep manajemen pengetahuan. Menurut (Mansell, 2010) dalam kehidupan masyarakat yang berbasis informasi, suatu 
pengetahuan (knowledge) merupakan dasar dari terbentuknya pendidikan dan kebudayaan masyarakat tersebut.

Learning Management System LMS adalah teknologi aplikasi untuk membuat sistem pelatihan yang terintegrasi dan sistem manajemen pengetahuan yang memungkinkan sebuah organisasi membagi pengetahuan mereka dan merubah pengetahuan menjadi sebuah sistem pelatihan dengan kata lain, LMS adalah pusat penghubung untuk pembelajaran, manajemen pengetahuan, manajemen prestasi, dan lain-lain. LMS sendiri dalam dunia pendidikan biasa disebut dengan elearning. Lebih khusus lagi, LMS adalah program untuk menyiapkan, mengatur, melihat dan melaporkan interaksi antara pembelajar dan isi bahan belajar, dan antara pembelajar dengan instruktur (Hudha et al., 2018; Rasyid \& Setiawardhana, 2006).

LMS yang digunakan untuk pembelajaran dalam jaringan saat ini di Universitas Negeri Manado yakni Aplikasi Amelia, dimana sistem komputer diimplementasikan di Internet/Intranet server yang menangani kegiatan dasar berikut ini : 1) Manajemen pengguna. Sistem harus memungkinkan masuk ke pengguna dengan profil yang berbeda dengan menggunakan password masing-masing yang telah diberikan untuk mahasiswa login menggunakan NIM sedangkan untuk dosen penanggung jawab menggunakan NIDN, misalnya: Dosen, Mahasiswa dan administrator sistem. 2) Manajemen administrasi pada virtual course. Hal ini membuat pelacakan mahasiswa, menyimpan semua dan setiap salah satu kegiatan mahasiswa yang dikembangkan pada sebuah fitur. Sebagai contoh, evaluasi dilakukan oleh mahasiswa untuk memperbaiki tingkat asimilasi isi dari courses adalah salah satu tugas-tugas administrasi yang paling penting. 3) Manajemen alat komunikasi. Komponen ini pada LMS merupakan dasar, sudut pandang, karena dapat dibangun dari berbagai kemungkinan yang berbeda, komunikasi antara para pelaku sistem yang berbeda. Alat-alat komunikasi dapat berupa forum, e-mail, konferensi video, chatting,group diskusi dan lain-lain (Alharbi \& Drew, 2014; Rani, Srivastava, \& Vyas, 2016; Rößling et al., 2008).

Fungsi dari LMS adalah: 1) Sentralisasi dan pengotomatisasian administrasi 2) Penggunaan layanan sendiri dan layanan panduan sendiri (Use self-service and self-guided services) 3) Mengumpulkan dan mengirimkan isi pembelajaran dengan cepat (Assemble and deliver learning content rapidly) 4) Konsolidasi inisiatif pelatihan pada platform berbasis web scalable (Consolidate training initiatives on a scalable web-based platform) 5) Dukungan portabilitas dan standar (Support portability and standards) 6) Personalisasi konten dan memungkinkan penggunaan kembali pengetahuan /Personalise content and enable Knowledge reuse (Muhammad, 2017; Yusro, Sasono, \& Primayoga, 2020).

Standar aplikasi yang dibuat bisa mendekati standard sebuah LMS: Interoperability, Reusability, Accessibility, Durability (Henriques, Slavov, \& Mendes, 2004). Permasalahan dalam pembelajaran ditengah kondisi saat ini menghadapi wabah corona virus disease (Covid19) Pemerintah melalui Kementerian Pendidikan dan Kebudayaan telah menerbitkan anjuran serta merujuk pada Surat Edaran Nomor 2 dan 3 Tahun 2020 Tentang Pencegahan dan Penanganan Corona Virus Disease (Covid- 19) Di Kementerian Pendidikan Dan Kebudayaan. Kemudian terbit Surat Edaran Nomor 30/Un41/Tu/2020 Tentang Tindakan Dalam Rangka Pencegahan Corona Virus Disease 2019 Covid-19 Di Universitas Negeri Manado Dikeluarkan Di Tondano 15 Maret 2020 Perkuliahan dilakukan secara online dengan menggunakan pembelajaran daring (Blended learning, e-learning, edmodo,google classroom, email dan penugasan baik UTS dan UAS dilakukan secara online).

Pada tanggal 23 Maret 2020 melalui web confrence Rektor UNIMA dengan jajaran pimpinan menyikapi kondisi yang terjadi hari-hari terakhir ini, pandemik global tentu didalamnya termasuk upaya kita menangkal covid-19. Maka jajaran khususnya di lingkungan UNIMA berupaya bagaimana proses belajar mengajar itu tetap berjalan dengan baik. Dan menghimbau memaksimalkan penggunaan teknologi informasi yang dapat mendukung proses belajar mengajar itu sendiri dengan melakukan pembelajaran dalam jaringan dengan mengoptimalkan penggunaan Learning Management System (LMS). akses Learning Management System UNIMA dengan mengaktifkan paket Ilmupedia pada aplikasi MyTelkomsel Gratis 30GB/30hari (https://amelia.unima.ac.id diakses 25 Juli 2020) 
Aplikasi Manajemen Perkuliahan Dalam Jaringan UNIMA (Amelia) merupakan layanan Universitas Negeri Manado untuk memfasilitasi pembelajaran blended learning secara efektif, efisien, dan bermutu.Amelia mobile (moodle). Tautan dalam aplikasi Amelia yakni Ristek DIKTI, SPADA Indonesia, Portal Garuda, Perpustakaan Nasional,Sinta. Terintegrasi dengan sistem akademik UNIMA dan SPADA Indonesia), Pembelajaran dapat dilakukan dimana saja dan kapan saja dengan lebih optimal atau powerful, Beragam Sumber belajar yang dapat dimanfaatkan dalam pembelajaran Dukungan SDM yang profesional dan berdedikasi tinggi, siap membantu kendala teknis dalam pengoperasi aplikasi Amelia.

Terdapat banyak penelitian yang memperkuat penelitian tentang pembelajaran dalam jaringan yakni mengukur tingkat kenyamanan penggunaan sistem e-learning moodle dalam proses knowledge sharing: studi kasus di universitas budi luhur (Solichin, 2009) aksesibilitas mahasiswa pada tutorial online program studi perpustakaan (Wahyuningsih, Rusli, \& Bintarti, 2015). Penggunaan e-learning sebagai media pembelajaran (Wiwin Hartono,2016) namun demikian pembahasan disesuaikan dengan fokus masing-masing meskipun pada umumnya membahas tentang pembelajaran e-learning sehingga pada kesempatan ini peneliti berusaha membahas salah satu aplikasi yang juga membantu dalam pembelajaran dalam jaringan yakni aplikasi Amelia di Jurusan Pendidikan Sejarah.

Urgensi penelitian ini bertujuan untuk mengungkapkan tentang efektivitas dari Pembelajaran dalam Jaringan menggunakan aplikasi Amelia,dimana aplikasi digunakan oleh mahasiswa dengan pengalaman baru mereka, seberapa besar usaha mereka beradaptasi dengan aplikasi yang baru mereka gunakan setelah belajar dalam jaringan. Sehingga penelitian ini diharapkan dapat memberikan kontribusi dalam peningkatan kualitas pembelajaran baik mahasiswa,dosen dan pengelola LMS untuk Aplikasi Amelia. Diharapkan lebih aktif belajar dengan memanfaatkan semua sumber daya belajar online Dengan belajar daring, mahasiswa dibiasakan bekerja secara mandiri, berkolaborasi, jujur, dan tepat waktu. Mahasiswa mampu mengecek kemajuan belajarnya sendiri pada menu Progress Report. Dosen dan mahasiswa dapat berdiskusi melalui fitur yang disediakan sehingga bersinergi membangun dan mengantarkan dalam peradaban dunia pendidikan yang berkualitas dan menguasai teknologi.

\section{Metode Penelitian}

Jenis penelitian yang digunakan dalam penelitian ini adalah penelitian kualitatif dengan metode survey deskriptif untuk mendeskripsikan berdasarkan dengan jawaban dari pembagian angket yang diberikan kepada mahasiswa. Untuk sampel pada penelitian ini adalah mahasiswa semester 2 angkatan 2019 sebanyak 38 mahasiswa Jurusan Pendidikan Sejarah Universitas Negeri Manado. Angket disebar menggunakan google form karena kondisi pandemi.Teknik pengumpulan data menggunakan kuesioner yang dibagikan ke mahasiswa untuk mengukur aspek yang berhubungan dengan penggunaan aplikasi Amelia, Seperti efektivitas, Kemudahan dalam akses,kemampuan menggunakan tools, alat yang digunakan untuk mengakses. Teknik analisis data berkenaan dengan perhitungan untuk menjawab rumusan masalah dan pengujian hipotesis yang diajukan. Bentuk hipotesis mana yang diajukan, akan menentukan teknik statistik mana yang akan digunakan.

Teknik analisis data dalam penelitian kuantitatif menggunakan statistik. Statistik deskriptif digunakan untuk menganalisis data yang telah terkumpul sebagaimana adanya tanpa bermaksud membuat kesimpulan yang berlaku untuk umum atau generalisasi. Termasuk dalam statistik deskriptif antaralain penyajian data melalui tabel,grafik,diagram lingkaran,perhitungan porsentase (Muyaroah \& Fajartia, 2017; Sugiyono, 2011).

\section{Hasil dan Pembahasan}

Pada awal maret 2020 merupakan kegiatan yang berhubungan dengan pembelajaran daring. Beberapa perwakilan jurusan diutus untuk mengikuti kegiatan tersebut. Sampai akhirnya proses belajar mengajar harus dilaksanakan secara daring. Dengan dukungan dari universitas 
pembelajaran dalam jaringan dilaksanakan dan Aplikasi Amelia menjadi salah satu aplikasi yang digunakan untuk proses pembelajaran.

Dosen mempunyai kewajiban untuk mengupload materi pembelajaran dalam aplikasi Amelia bertugas menyiapkan dan mengunggah semua konten kursus online, termasuk slide PowerPoint, artikel dan makalah yang relevan, tautan ke situs web yang bermanfaat, klip audio dan video, klip podcasting, instruksi penugasan, penandaan, dan umpan balik dan sebagainya (Bentley, Selassie, \& Shegunshi, 2011) .

Kegiatan tatap muka yang biasa dilaksanakan dialihkan ke pembelajaran daring. Perkuliahan dimulai sesuai dengan jadwal perkuliahan yang berjalan. Notifikasi tambahan disampaikan didalam group whatssapp angkatan. Adapaun untuk proses diskusi terkait materi yang telah dibagikan dilaksanakan dalam aplikasi Amelia. Mahasiswa diminta untuk memantau materi didalam aplikasi Amelia, Kontrak perkuliahan dijalankan sesuai kesepakatan awal. Dimulai dari kehadiran, Absen disiapkan dalam setiap pertemuan, Pre Test, Materi, Penjelasan tambahan tentang materi, post test dan group diskusi dalam setiap pertemuan. Tugas untuk semua materi dalam setiap pertemuan dikirim ke mahasiswa secara online

E-learning didefinisikan sebagai pelayanan pendidikan (semua kegiatan yang relevan untuk menginstruksikan, mengajar, dan belajar) melalui berbagai media elektronik (Koohang, Smith, et al., 2010). Strategi penggunaan e-learning untuk menunjang pelaksanaan proses belajar, diharapkan dapat meningkatkan daya serap dari peserta didik atas materi yang diajarkan; meningkatkan partisipasi aktif dari peserta didik; meningkatkan kemampuan belajar mandiri peserta didik; meningkatkan kualitas materi pendidikan dan pelatihan, meningkatkan kemampuan menampilkan informasi dengan perangkat teknologi informasi, memperluas daya jangkau proses belajar-mengajar dengan menggunakan internet, tidak terbatas pada ruang dan waktu (Koohang, Floyd, Smith, \& Skovira, 2010). Untuk mencapai hal-hal tersebut di atas, dalam pengembangan suatu aplikasi e-learning perlu diperhatikan bahwa materi yang ditampilkan harus menunjang penyampaian informasi yang benar, tidak hanya mengutamakan sisi keindahan saja; memperhatikan dengan seksama teknik belajar-mengajar yang digunakan; memperhatikan teknik evaluasi kemajuan peserta didik dan penyimpanan data kemajuan peserta didik.

Materi dari proses pembelajaran dapat diambil dari sumber-sumber yang valid dan dengan teknologi e-learning, materi bahkan dapat diproduksi berdasarkan sumber dari tenagatenaga ahli (experts). Misalnya, tampilan video digital yang menampilkan seorang ahli pemasaran menunjukkan bagaimana caranya melakukan penataan produk dalam suatu retail. Dengan animasi 3 dimensi dapat ditunjukkan bagaimana langkah-langkah penyusunan dengan benar dalam menerapkan strategi penyusunan produk untuk berbagai macam jenis produk yang berbeda. Dalam penerapan teknologi seperti penggunaan e-learning, perlu di formulasikan strategi yang jelas sebagai acuan. Penyusunan strategi e-learning seperti disampaikan (Empy \& Hartono, 2005) berguna untuk (1) memperjelas tujuan pelatihan atau pendidikan yang ingin dicapai (2) mengetahui sumber daya yang dibutuhkan (3) membuat semua pihak yang terlibat untuk tetap mengacu pada tujuan yang sama. (4) mengetahui pengukuran keberhasilan.

Strategi e-learning melibatkan empat tahap yaitu analisis, perencanaan, pelaksanaan dan evaluasi. Analisis, factor-faktor yang perlu dianalisis diantaranya kebutuhan organisasi dalam melihat keadaan sekarang dan keberadaan e-learning dalam memberikan dampak positif. Selain kebutuhan organisasi juga perlu dianalisis tentang infrastruktur organisasi terhadap pelaksanaan penggunaan e-learning. Perencanaan, aspek perencanaan yang harus ditinjau yaitu network, learning management system, materi dan manajemen pengelolaan. Pelaksanaan, tahap ini memerlukan keahlian project management yang baik untuk memastikan koordinasi dan eksekusi pekerjaan sesuai rencana dan tidak menyimpang dari tujuan dan strategi. Evaluasi, setelah melaksanakan rencana penerapan e-learning, selanjutnya me menilai keberhasilan program.

Setelah strategi e-learning diterapkan maka perlu diukur efektivitasnya. Jangkauan usaha suatu program sebagai suatu sistem dengan sumber daya dan sarana tertentu untuk memenuhi tujuan dan sasarannya tanpa melumpuhkan cara dan sumber daya itu serta tanpa 
memberi tekanan yang tidak wajar terhadap pelaksanaannya. Dalam pembelajaran diperlukan perencanaan yang matang, pembuatan perangkat pembelajaran, pemilihan strategi, media, teknik, model pembelajaran, hingga evaluasi pembelajaran yang semua itu saling berkesinambungan. Perlunya penggunaan model - model pembelajaran yang efektif dan inovatif agar dalam pembelajaran yang dilakukan dapat lebih variatif dan berjalan lancar. Penggunaan model pembelajaran tersebut juga disesuaikan dengan materi yang akan diajarkan sehingga kesesuaian antara keduanya dan semua komponen menjadi tepat guna.

Adapun hasil pengukuran tingkat efektivitas penggunaan Aplikasi Amelia sebagai media pembelajaran dalam e-learning dapat dilihat pada diagram 1.

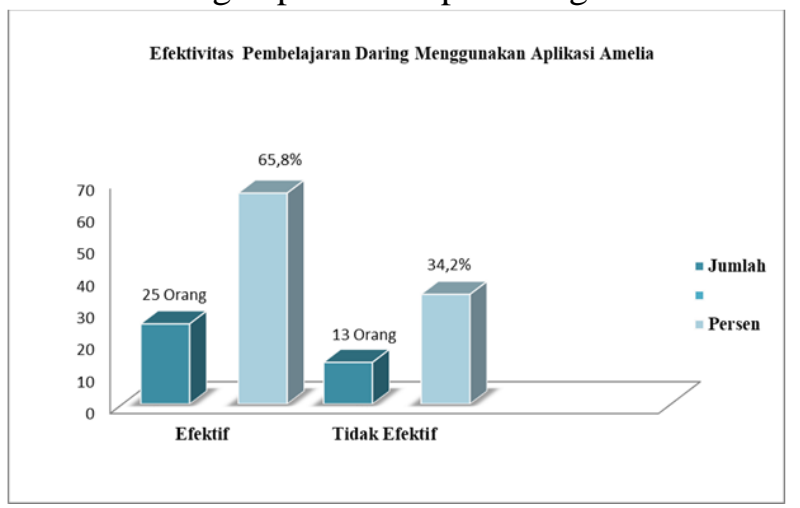

\section{Gambar 1. Efektivitas Pembelajaran Daring Menggunakan Aplikasi Amelia}

Mahasiswa yang mengisi angket dari semester 2 terdapat 38 orang, dan dari pertanyan tentang efektivitas terdapat 25 orang atau sebanyak $65,8 \%$ mengungkapkan efektif menggunakan aplikasi Amelia dalam pembelajaran daring, 13 orang atau sebanyak 34,2\% yang mengatakan bahwa kurang efektif. Indikasi yang bisa terlihat dari Gambar 1 menunjukkan sejauh ini upaya untuk tetap melakukan proses pembelajaran karena kondisi yang mengharuskan semua dilakukan dengan jaga jarak sementara proses pembelajaran harus tetap dilanjutkan sehingga Penggunaan Aplikasi Amelia dianggap sangat membantu.

Aksesibilitas adalah kemudahan mengakses tujuan yang dapat memberikan kenyamanan beraktivitas (Widyonarso \& Yuliastuti, 2014). Agar pengguna atau mahasiswa dapat mencari sesuatu yang dibutuhkan dapat dengan cepat, tepat dan sesuai sasaran, teknologi informasi dan komunikasi sangatlah membantu mencari informasi yang dibutuhkan. Ditambah perkembangan jaringan internet yang telah masuk sampai ke daerah-daerah memudahkan mahasiswa mencari dan mengakses informasi yang tersebar di dunia tanpa harus pergi ke suatu tempat. Kemudahan dalam akses aplikasi Amelia dapat terlihat pada diagram Gambar 2.

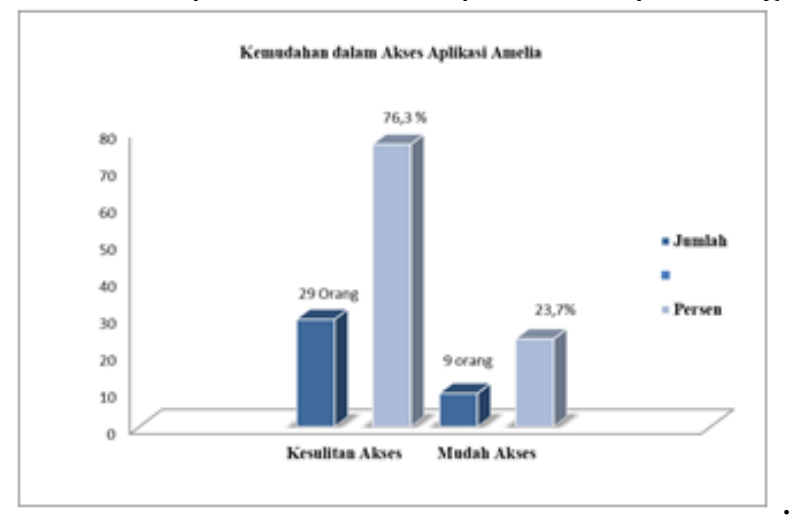

Gambar 2. Diagram Gambar Kemudahan dalam Akses Aplikasi Amelia 
Akses mempunyai pengaruh yang kuat terhadap tingkat partisipasi mahasiswa dalam pembelajaran melalui media internet. Pengertian akses terhadap media terkait erat dengan aspek ketersediaan dan kemudahan memperoleh atau menggunakan Aplikasi Amelia dengan didukung koneksi internet yang stabil. Gambar 2 memperlihatkan kesulitan akses terdapat 29 orang atau sekitar 76,3\% dikarenakan koneksi internet yang kurang stabil maupun karena keterbatasan kuota, Web kadang susah dibuka dan Sering mati lampu. Sebanyak 9 orang atau 23,7\% mengatakan mudah mengakses yang mewakili pernyataan tidak ada kendala dalam pelaksanaan pembelajaran daring. Dengan demikian, salah satu komponen utama dari pembelajaran menggunakan e-learning adalah adanya suatu tools atau media teknologi yang dapat mendukung penuh proses knowledge sharing yang terjadi antara pengajar (dosen, guru) dan pelajar (siswa, mahasiswa). Tools atau media tersebut umumnya berupa sistem atau aplikasi yang disebut Learning Management System (LMS) atau Virtual Learning Environment (VLE). Contoh LMS yang banyak digunakan dalam penerapan e-learning antara lain Moodle (http:// Moodle.org) sebagaimana aplikasi Amelia. Kemampuan menggunakan Fitur Aplikasi Amelia dapat dilihat pada diagram gambar 3.

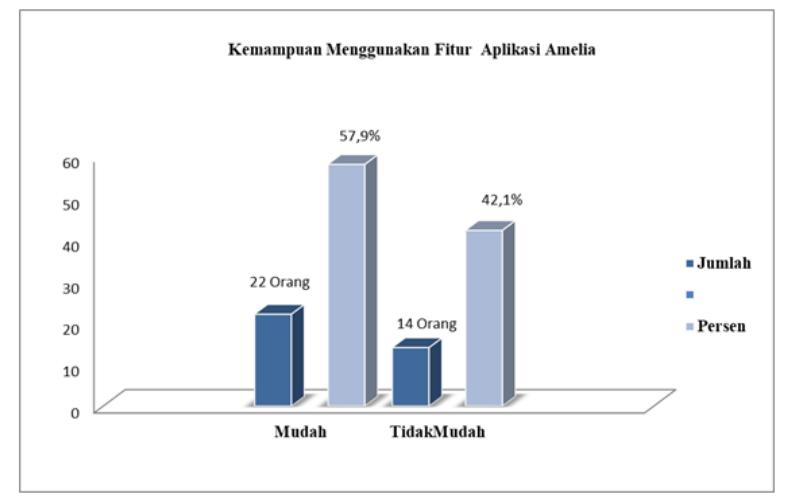

\section{Gambar 3. Diagram Kemampuan Menggunakan Fitur Aplikasi Amelia}

Sebanyak 22 orang atau 57,9\% mengatakan mudah dalam menggunakan fitur yang sudah tersedia dalam aplikasi Amelia. Ini terlihat partisipasi aktif mereka dalam setiap pertemuan, semua tahapan dalam pertemuan dimulai dari absen, pre test, materi, post test sampai dengan group diskusi terlihat mahasiswa aktif dan menggunakan dengan baik dan maksimal. Sedangkan 14 orang atau sebanyak 42,1\% mengatakan tidak mudah, apalagi Aplikasi ini terbilang baru untuk mereka dan pengerjaan tugas secara full dalam jaringan untuk mahasiswa semester 2 adalah pengalaman perdana mereka. Apabila terdapat kendala dalam perkuliahan mereka dapat menanyakan langsung didalam group Whatsapp mereka.

Penggunaan alat elektronik untuk mengakses aplikasi Amelia bisa dilihat dalam diagram gambar 4.

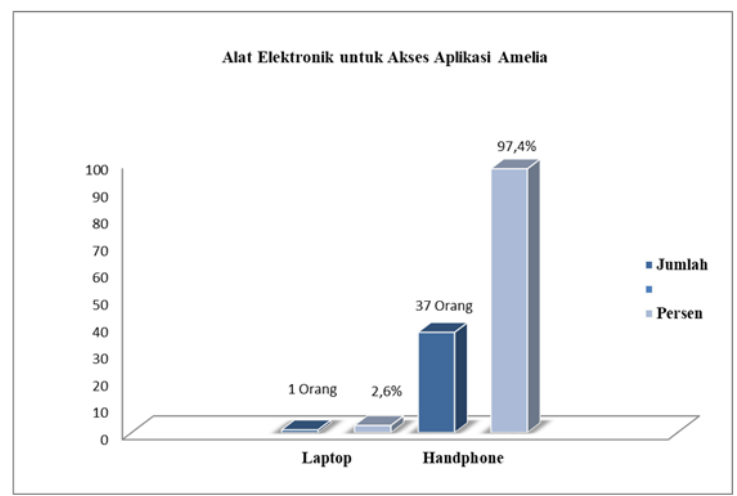

Gambar 4. Diagram Alat Elektronik untuk Akses Aplikasi Amelia 
Dari gambar 4 bisa terlihat hasil dari penggunaan laptop terdapat 1 orang atau sebesar 2,6\%, dan selebihnya 37 orang atau sekitar 97,4\% menggunakan handphone untuk mengakses pembelajaran dalam jaringan. Dari indikator yang telah diukur melalui pembagian angket peneliti berupaya untuk merumuskan masalah yang dihadapi dalam pembelajaran online dari berbagai aspek seperti materi ajar, interaksi belajar, dan lingkungan belajar (Fortune, M. F., Spielman, M., \& Pangelinan, 2011). Dengan demikian pembelajaran dalam jaringan dapat dilakukan di manapun mahasiswa dan dosen berada. Sehingga mampu menciptakan nuansa yang sama atau sekurangnya mendekati dengan aktivitas dan psikologi belajar dalam pembelajaran tatap muka.

\section{Simpulan}

Mahasiswa merasa efektif dalam pembelajaran daring menggunakan Aplikasi Amelia dimasa Pandemi ini yang mengharuskan untuk menjaga jarak dan tidak mengadakan perkuliahan tatap muka langsung yang ditandai dengan sejumlah peraturan dari kementerian pendidikan dan kebudayaan serta dari pihak institusi langsung.Keberhasilan pembelajaran dalam jaringan ditunjang oleh adanya interaksi maksimal antara pendidik dan peserta didik, antara peserta didik dengan berbagai fasilitas pendidikan, antara peserta didik dengan peserta didik lainnya, dan adanya pola pembelajaran aktif dalam interaksi tersebut. Apabila pembelajaran bebasis pada web, maka diperlukan adanya pusat kegiatan peserta didik, interaksi antar kelompok, administrasi penunjang sistem, pendalaman materi, ujian, dan materi online. Dari sisi teknologi informasi; internet memungkinkan perombakan total konsep-konsep pembelajaran yang selama ini berlaku. Studi ini mengeksplorasi bagaimana pembelajaran dalam jaringan dukungan dari dosen atau pengajar dalam mendorong terjadinya knowledge sharing (tutor support). Kesulitan dan kekurangan yang terdapat dalam aplikasi Amelia rekomendasi untuk penelitian dan praktik di masa depan.

\section{Daftar Pustaka}

Alharbi, S., \& Drew, S. (2014). Using the Technology Acceptance Model in Understanding Academics' Behavioural Intention to Use Learning Management Systems. International Journal of Advanced Computer Science and Applications, 5(1), 143-155. https://doi.org/10.14569/ijacsa.2014.050120

Bentley, Y., Selassie, H., \& Shegunshi, A. (2011). Student-focused elearning design and evaluation. Proceedings of the International Conference on E-Learning, ICEL, (March 2012), 53-61.

Empy, E., \& Hartono, Z. (2005). E-learning Konsep dan Aplikasi. Yogyakarta: Andi Offset.

Fortune, M. F., Spielman, M., \& Pangelinan, D. T. (2011). Students' Perceptions of Online or Face-to-Face Learning and Social Media in Hospitality, Recreation and Tourism. . . MERLOT Journal of Online Learning and Teaching, 7(1), 1-16.

Halawi, L. A., McCarthy, R. V., \& Aronson, J. E. (2007). An empirical investigation of knowledge management systems' success. Journal of Computer Information Systems, 48(2), 121-135. https://doi.org/10.1080/08874417.2008.11646014

Henriques, N., Slavov, D., \& Mendes, A. J. (2004). LearningOnWeb: Development of a SCORM Compliant Learning Management System. Proceedings of the 5th International Conference on Computer Systems and Technologies, 1-6. Retrieved from 
http://doi.acm.org/10.1145/1050330.1050418

Hudha, M. N., Chaeruman, U. A., Aji, S. D., Huda, C., Yusro, A. C., Kumala, F. N., ... Abdullah, A. G. (2018). SPADA: Online learning between universities of PGRI Indonesia. $\begin{array}{llll}\text { MATEC Web of } & 03002 .\end{array}$ https://doi.org/10.1051/matecconf/201819703002

Koohang, A., Floyd, K., Smith, T., \& Skovira, R. (2010). The Hype of Using Social Networking as a Tool for Learning in E-Learning. Issues in Information Systems, 11(2), 30-36.

Koohang, A., Smith, T., Floyd, K., Skovira, R., Kohun, F., \& Delorenzo, G. (2010). Panel Discussion: The State of Blended Learning. In Proceedings of the 2010 InSITE Conference (pp. 705-708). https://doi.org/10.28945/1284

Mansell, R. (2010). The information society and ICT policy: A critique of the mainstream vision and an alternative research framework. Journal of Information, Communication and Ethics in Society, 8(1), 22-41. https://doi.org/10.1108/14779961011024792

Muhammad, T. (2017). Perancangan Learning Management System Menggunakan Konsep Computer Supported Collaborative Learning. Jurnal Produktif, 1, 35-63.

Muyaroah, S., \& Fajartia, M. (2017). Pengembangan Media Pembelajaran Berbasis Android dengan menggunakan Aplikasi Adobe Flash CS 6 pada Mata Pelajaran Biologi. Innovative Journal of Curriculum and Educational Technology, 6(2), 22-26. https://doi.org/10.15294/ijcet.v6i2.19336

Rani, M., Srivastava, K. V., \& Vyas, O. P. (2016). An ontological learning management system. Computer Applications in Engineering Education, 24(5), 706-722. https://doi.org/10.1002/cae.21742

Rasyid, M. U. H. Al, \& Setiawardhana. (2006). Evaluation Management System Berbasis Web Untuk Mendukung Penilaian Tes Online. Seminar Nasional Aplikasi Teknologi Informasi (SNATI 2006), 2006(Snati), 71-76. Retrieved from file:///C:/Users/Windows 10/Downloads/1506-1346-1-PB.pdf

Rößling, G., Joy, M., Moreno, A., Radenski, A., Malmi, L., Kerren, A., ... Iturbide, J. Á. V. (2008). Enhancing learning management systems to better support computer science education. ACM SIGCSE Bulletin, 40(4), 142-166. https://doi.org/10.1145/1473195.1473239

Solichin, A. (2009). Mengukur Tingkat Kenyamanan Penggunaan Sistem E-learning Moodle dalam Proses Knowledge Sharing: Studi Kasus di Universitas Budi Luhur. Budi Luhur Information Technology (BIT), 6(1), 43-50.

Sugiyono. (2011). Metode Penelitian Kuantitatif, Kualitatif dan $R \& D$. Bandung: Afabeta.

Wahyuningsih, S. S., Rusli, Y., \& Bintarti, A. (2015). Aksesibilitas Mahasiswa Pada Tutorial Online Program Studi Perpustakaan. Jurnal Pendidikan Terbuka Dan Jarak Jauh, 16(1), 29-38.

Widyonarso, E., \& Yuliastuti, N. (2014). Tingkat Aksesibilitas Fasilitas Sosial Berdasarkan Konsep Unit Lingkungan Di Perumnas Banyumanik Kota Semarang. Ruang: Jurnal Perencanaan Wilayah Dan Kota, 2(4), 351-360.

Yusro, A. C., Sasono, M., \& Primayoga, G. (2020). The influence of active involvement on learning outcomes of physics pre-service teachers: A case study of blended learning on statistics course. Momentum: Physics Education Journal, 4(1), 30-37. https://doi.org/10.21067/mpej.v4i1.4194 